NASA/TM-2006-214422

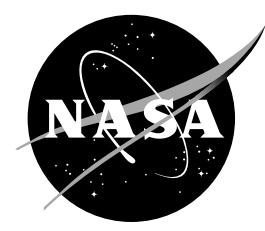

\title{
Wearable Wireless Telemetry System for Implantable Bio-MEMS Sensors
}

Rainee N. Simons, Félix A. Miranda, and Jeffrey D. Wilson

Glenn Research Center, Cleveland, Ohio

Renita E. Simons

John Carroll University, University Heights, Ohio 


\section{NASA STI Program . . . in Profile}

Since its founding, NASA has been dedicated to the advancement of aeronautics and space science. The NASA Scientific and Technical Information (STI) program plays a key part in helping NASA maintain this important role.

The NASA STI Program operates under the auspices of the Agency Chief Information Officer. It collects, organizes, provides for archiving, and disseminates NASA's STI. The NASA STI program provides access to the NASA Aeronautics and Space Database and its public interface, the NASA Technical Reports Server, thus providing one of the largest collections of aeronautical and space science STI in the world. Results are published in both non-NASA channels and by NASA in the NASA STI Report Series, which includes the following report types:

- TECHNICAL PUBLICATION. Reports of completed research or a major significant phase of research that present the results of NASA programs and include extensive data or theoretical analysis. Includes compilations of significant scientific and technical data and information deemed to be of continuing reference value. NASA counterpart of peer-reviewed formal professional papers but has less stringent limitations on manuscript length and extent of graphic presentations.

- TECHNICAL MEMORANDUM. Scientific and technical findings that are preliminary or of specialized interest, e.g., quick release reports, working papers, and bibliographies that contain minimal annotation. Does not contain extensive analysis.

- CONTRACTOR REPORT. Scientific and technical findings by NASA-sponsored contractors and grantees.
- CONFERENCE PUBLICATION. Collected papers from scientific and technical conferences, symposia, seminars, or other meetings sponsored or cosponsored by NASA.

- SPECIAL PUBLICATION. Scientific, technical, or historical information from NASA programs, projects, and missions, often concerned with subjects having substantial public interest.

- TECHNICAL TRANSLATION. Englishlanguage translations of foreign scientific and technical material pertinent to NASA's mission.

Specialized services also include creating custom thesauri, building customized databases, organizing and publishing research results.

For more information about the NASA STI program, see the following:

- Access the NASA STI program home page at http://www.sti.nasa.gov

- E-mail your question via the Internet to help@sti.nasa.gov

- Fax your question to the NASA STI Help Desk at 301-621-0134

- Telephone the NASA STI Help Desk at 301-621-0390

- Write to:

NASA STI Help Desk

NASA Center for AeroSpace Information 7121 Standard Drive Hanover, MD 21076-1320 
NASA/TM-2006-214422

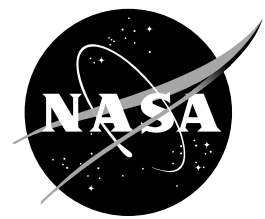

\section{Wearable Wireless Telemetry System for Implantable Bio-MEMS Sensors}

Rainee N. Simons, Félix A. Miranda, and Jeffrey D. Wilson

Glenn Research Center, Cleveland, Ohio

Renita E. Simons

John Carroll University, University Heights, Ohio

Prepared for the

28th Annual International Conference (IEEE EMBC 2006)

sponsored by the Institute of Electrical and Electronics Engineers Engineering in Medicine and Biology Society (EMBS)

New York City, New York, August 30-September 3, 2006

National Aeronautics and

Space Administration

Glenn Research Center

Cleveland, Ohio 44135 
This report contains preliminary findings, subject to revision as analysis proceeds.

Trade names and trademarks are used in this report for identification only. Their usage does not constitute an official endorsement, either expressed or implied, by the National Aeronautics and Space Administration.

Level of Review: This material has been technically reviewed by technical management.

Available from

NASA Center for Aerospace Information 7121 Standard Drive

Hanover, MD 21076-1320
National Technical Information Service 5285 Port Royal Road Springfield, VA 22161 


\title{
Wearable Wireless Telemetry System for Implantable Bio-MEMS Sensors
}

\author{
Rainee N. Simons, Félix A. Miranda, and Jeffrey D. Wilson \\ National Aeronautics and Space Administration \\ Glenn Research Center \\ Cleveland, Ohio 44135 \\ Renita E. Simons \\ John Carroll University \\ University Heights, Ohio 44118
}

\begin{abstract}
In this paper, a telemetry and contact-less powering system consisting of an implantable bio-MEMS sensor with a miniature printed square spiral chip antenna and an external wearable garment with printed loop antenna is investigated. The wearable garment pick-up antenna and the implantable chip antenna are in close proximity to each other and hence couple inductively through their near-fields and behave as the primary and the secondary circuits of a transformer, respectively. The numerical and experimental results are graphically presented, and include the design parameter values as a function of the geometry, the relative magnetic near-field intensity as a function of the distance and angle and the current density on the strip conductors, for the implantable chip antenna.
\end{abstract}

\section{Introduction}

In human space exploration programs there are several situations such as space and planetary surface extravehicular activity (EVA), launch and de-orbit, and physical exercise in microgravity that require noninvasive monitoring of the physiological parameters, including blood pressure, heart rate, oxygen, etc. (ref. 1). The sensors used in monitoring these parameters have to be small, light weight, wearable and inductively powered. In addition, the data from these sensors have to be wirelessly transmitted and recorded. Furthermore, the recorded data have to be periodically uploaded to a database server via a wireless local area network (LAN) for assessment. As an example, the progress to date by our group and others in the development of implantable bio-MEMS based sensor system for monitoring pressure is presented in (ref. 2). These sensors operate in the unlicensed frequency band and the frequency, power, and range of operation, as well as the dielectric properties of the human body are summarized in table I. Moreover, wearable sensors and systems for unobtrusive and continuous monitoring of the vital signs of humans have recently made significant advances (ref. 3). Hence integrating the two technologies would enable higher mobility and greater connectivity.
In this paper, a wearable wireless telemetry and contact-less powering scheme for an implantable bio-MEMS based sensor system is presented. The scheme is illustrated via a spinal implant and a wearable unit as depicted in figure 1. Integrated with the implantable bio-MEMS sensor and the wearable garment are a miniature $(1 \times 1 \mathrm{~mm})$ printed square spiral chip antenna and a pick-up loop antenna/signal processing circuits $(5 \times 5 \mathrm{~cm})$, respectively. The miniature implantable sensor antenna is modeled as a square spiral chip inductor and the computed inductance, parasitic resistance and capacitance are presented. In addition, the implantable antenna and the proximity garment pick-up antenna are coupled via the near-fields and hence the computed mutual inductance is presented. Furthermore, a lumped element equivalent circuit model taking into consideration the mutual inductance, and the near-zone magnetic field intensity pattern of the implantable antenna, are presented. Lastly, the computed RF magnetic near-field intensity and the current density on the strip conductors using finite difference time domain and method of moments software tools, respectively, are presented.

\section{Implantable Square Spiral Chip Inductor/Antenna}

The miniature printed square spiral chip inductor/antenna is illustrated in figure 2(a). A photomicrograph of the circuit fabricated on a high resistivity silicon wafer $\left(\varepsilon_{\mathrm{r}}=11.7\right)$ is shown in figure 2(b). The circuit is modeled as a series inductor $L_{S}$ and resistor $R_{S}$ in parallel with a capacitor $C_{S}$. The $L_{S}$ is computed using the current sheet expression given in reference 4 and the $\mathrm{R}_{\mathrm{S}}$ and $\mathrm{C}_{\mathrm{S}}$ are computed using the expressions given in reference 5 . In computing $R_{S}$ the conductor thickness is assumed to be equal to one skin depth at the operational frequency of $403 \mathrm{MHz}$. The computed $\mathrm{R}_{\mathrm{S}}, \mathrm{L}_{\mathrm{S}}$, and $\mathrm{C}_{\mathrm{S}}$ as a function of the strip width $\mathrm{W}$ and the number of turns $\mathrm{N}$ for a fixed strip separation $\mathrm{S}$ are presented in figures 3 to 5, respectively. The experimental data point in figure 4 is for the inductor shown in figure 2(b). 


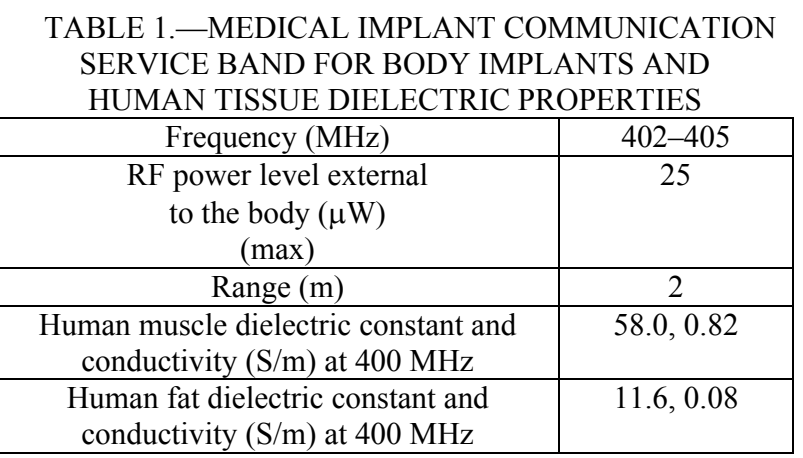

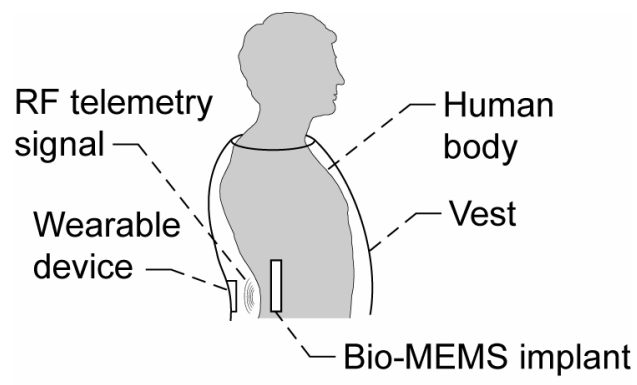

Figure 1.-Contact-less powering and telemetry concept for wearable Bio-MEMS sensors.
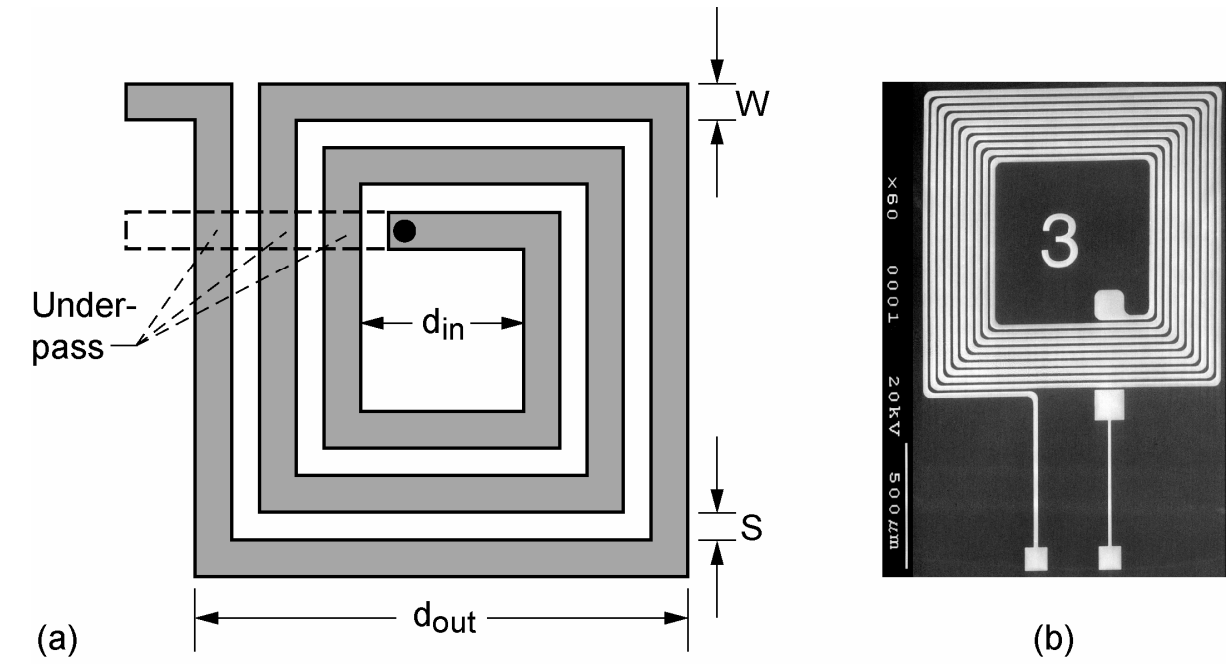

(b)

Figure 2.-(a) Schematic of a miniature printed squares spiral inductor/antenna. $\mathrm{d}_{\text {in }}=0.5 \mathrm{~mm}, \mathrm{~S}=10 \mu \mathrm{m}$, conductor is gold and thickness $=1.5 \mu \mathrm{m}$. (b) Photomicrograph of inductor/antenna.

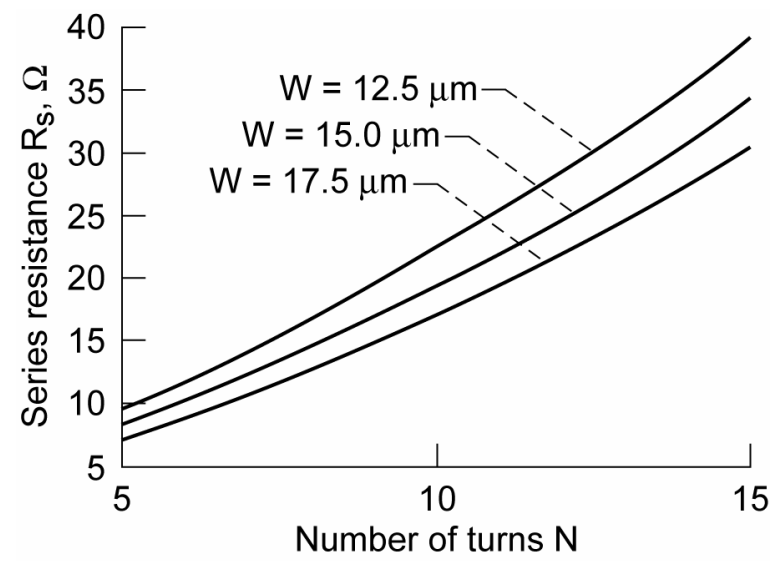

Figure 3.-Series resistance as a function of the number of turns for different strip widths.

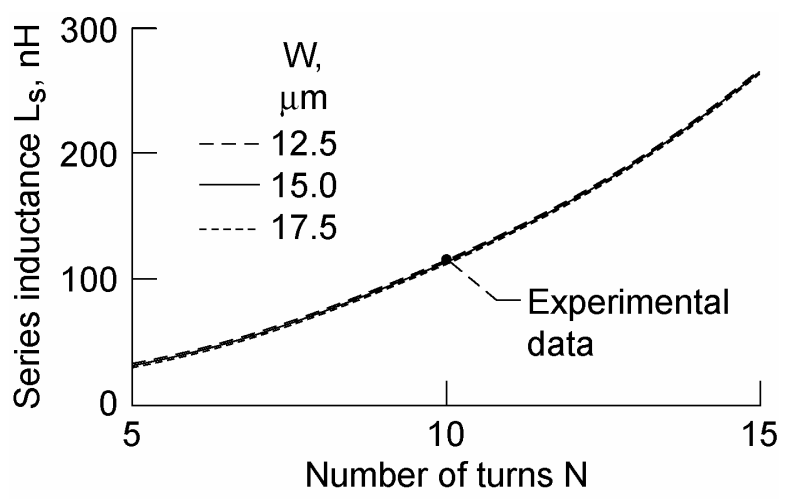

Figure 4.-Series inductance as a function of the number of turns for different strip widths. 


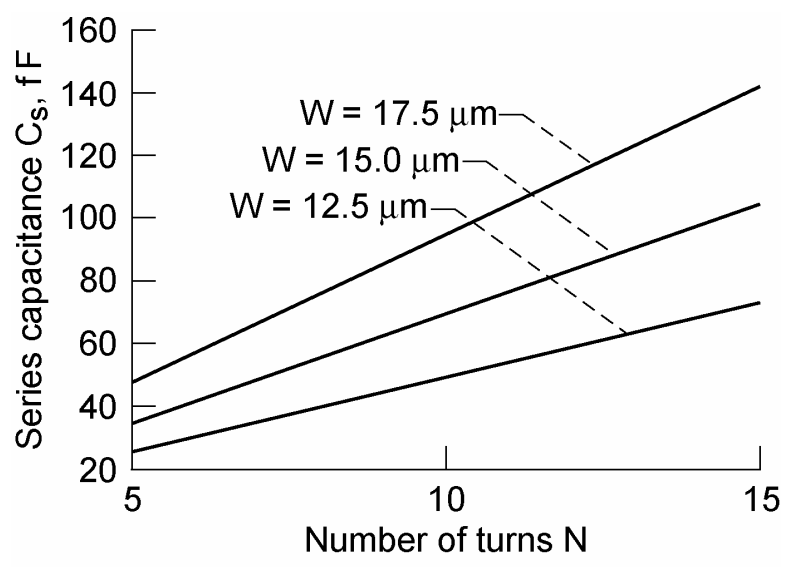

Figure 5.-Series capacitance as a function of the number of turns for different strip widths, the insulating dielectric is polyimide $\left(\varepsilon_{r}=3.5\right)$ and thickness $=1 \mu \mathrm{m}$.

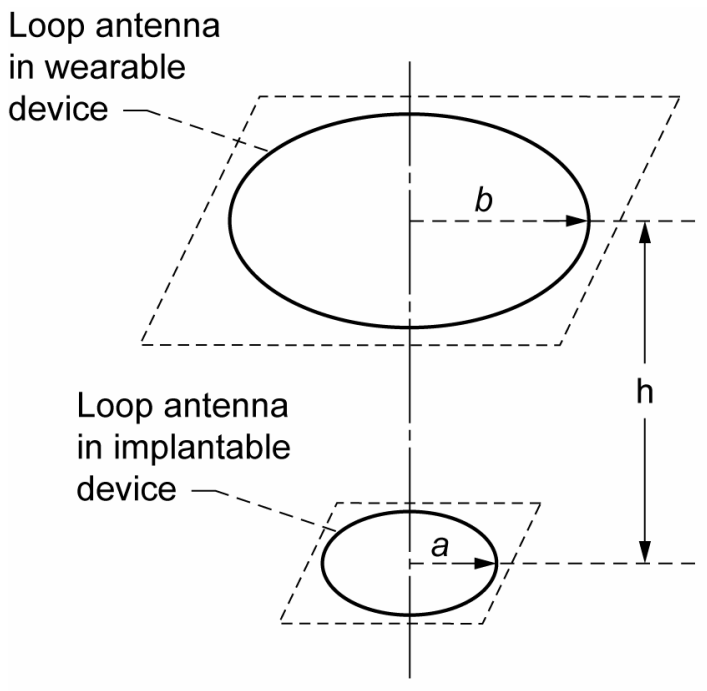

Figure 6.--Inductively coupled coaxial circular loop antennas in air, $h$ is the separation between the antennas.

\section{Equivalent Circuit Model for Inductively Coupled Square Spiral Chip and Loop Antennas}

To determine the mutual inductance $\mathrm{M}$, the miniature printed square spiral chip inductor/antenna and the pick-up loop antenna are modeled as two circular filamentary current paths of radius $a$ and $b$, respectively, as shown in figure 6 . Based on the expression in reference 6 , the computed $\mathrm{M}$ as a function of the implantable antenna radius $a$, for a fixed separation h, is presented in figure 7 . In addition, the inductively coupled spiral and loop antennas are modeled as an equivalent transformer (ref. 7) as shown in figure 8. In this model, $R_{p}$ and $L_{p}$ represent the loss resistance and self-inductance of the external

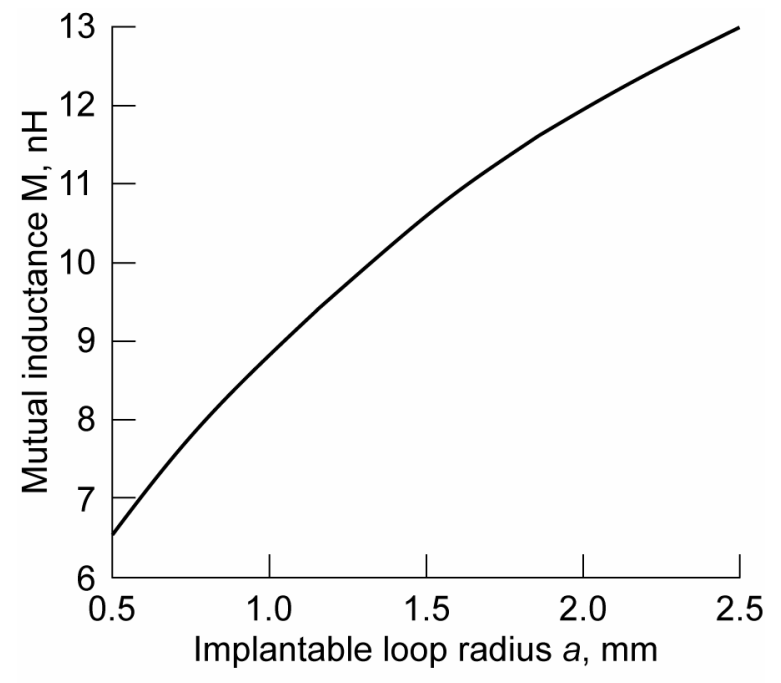

Figure 7.-Mutual inductance as a function of the implantable loop radius for $\mathrm{h}=5 \mathrm{~cm}$ and $\mathrm{b}=2.55 \mathrm{~cm}$.

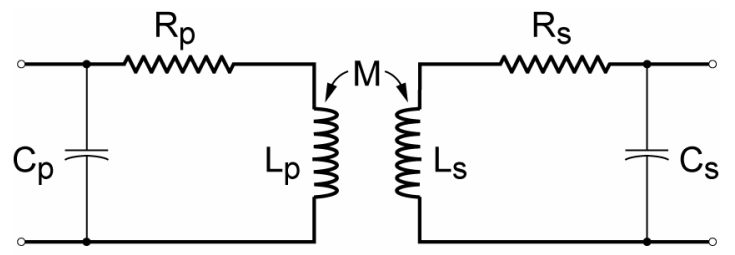

Figure 8.-The inductivity coupled loop and spiral are modeled as an equivalent transformer circuit, $R_{p}=3.45 \Omega, L_{p}=0.43 \mu \mathrm{H}$.

pick-up loop antenna. The capacitance $\mathrm{C}_{\mathrm{p}}$ is part of the input impedance matching circuit. This model would be used to compute the input impedance for designing a matching circuit.

\section{Near-Field Pattern of Implantable Square Spiral Chip Antenna Array}

The radiation characteristics of a single miniature square spiral chip antenna have been analyzed and presented in reference 7. To provide greater circumferential coverage along the torso our implantable sensor has two miniature square spiral chip antennas, with equal amplitude and phase excitation, as illustrated in figure 9. For the purpose of analysis, the individual chip antennas are approximated by a single turn loop of radius $a$, with constant current distribution $\mathrm{I}_{0}$, and circumference less than one-tenth of a wavelength. Under these assumptions, the near-zone RF magnetic fields are given by the expressions in reference 8 . From these expressions the total near-zone RF magnetic field as a function of the azimuth angle $\theta$ is computed and presented in figure 10. In addition, using the full-wave three-dimensional finite difference time domain electromagnetic analysis software, Remcom XFDTD (Remcom) (ref. 9), the near-zone RF magnetic field components as a function of the distance is 


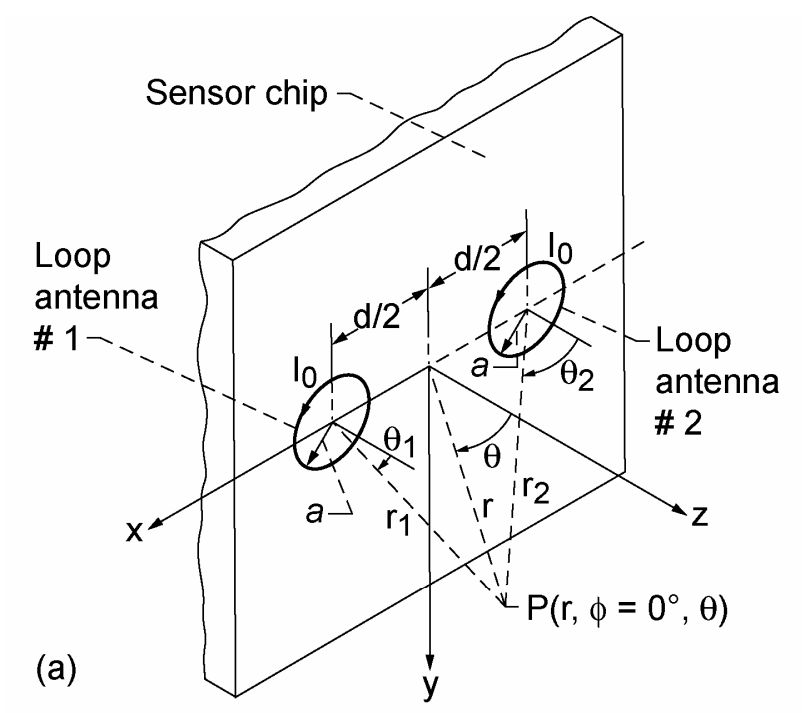

Figure 9.-(a) Sensor antenna array, $a=1 \mathrm{~mm}, \mathrm{~d}=2.5 \mathrm{~mm}$

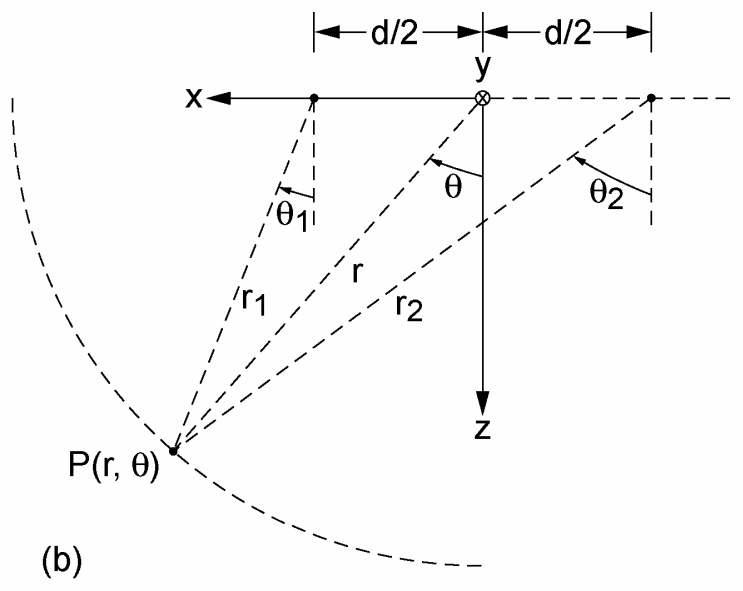

(b) Coordinate system for computing the RF near field.

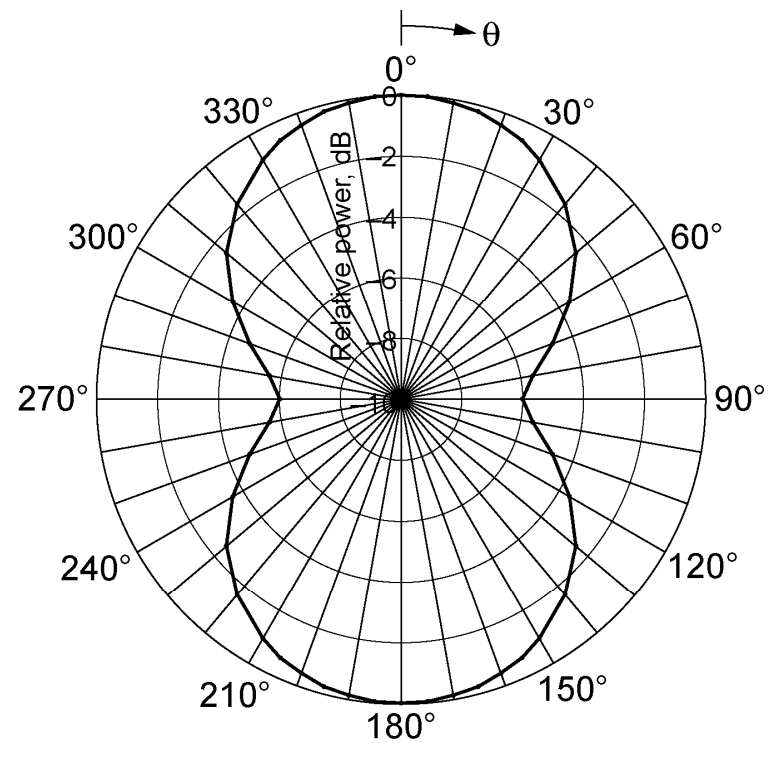

Figure 10.-Computed near-zone total RF magnetic field intensity in the $x-z$ plane, frequency $=403 \mathrm{MHz}$, $r=10 \mathrm{~cm}$ and $\mathrm{I}_{0}=1 \mathrm{~mA}$.

computed. In figure 11, a span shot of the simulated intensity of the magnetic field components, $\mathrm{H}_{\mathrm{x}}, \mathrm{H}_{\mathrm{y}}$, and $\mathrm{H}_{\mathrm{z}}$ after one $\mathrm{RF}$ period, as a function of the distance from the center of a singleturn spiral antenna in the $\mathrm{y}-\mathrm{z}$ plane, is presented. The maximum distance is $5 \mathrm{~cm}$ in the $\mathrm{z}$-direction, which is typical for positioning a receiver in a wearable sensor application. The results for a multi-turn spiral will be presented in a future paper. Furthermore, the current density on the strip conductors of a simplified threeturn spiral antenna computed using the full-wave threedimensional method of moments based electromagnetic software, Sonnet (Sonnet Software, Inc.) (ref. 10) is presented in figure 12.

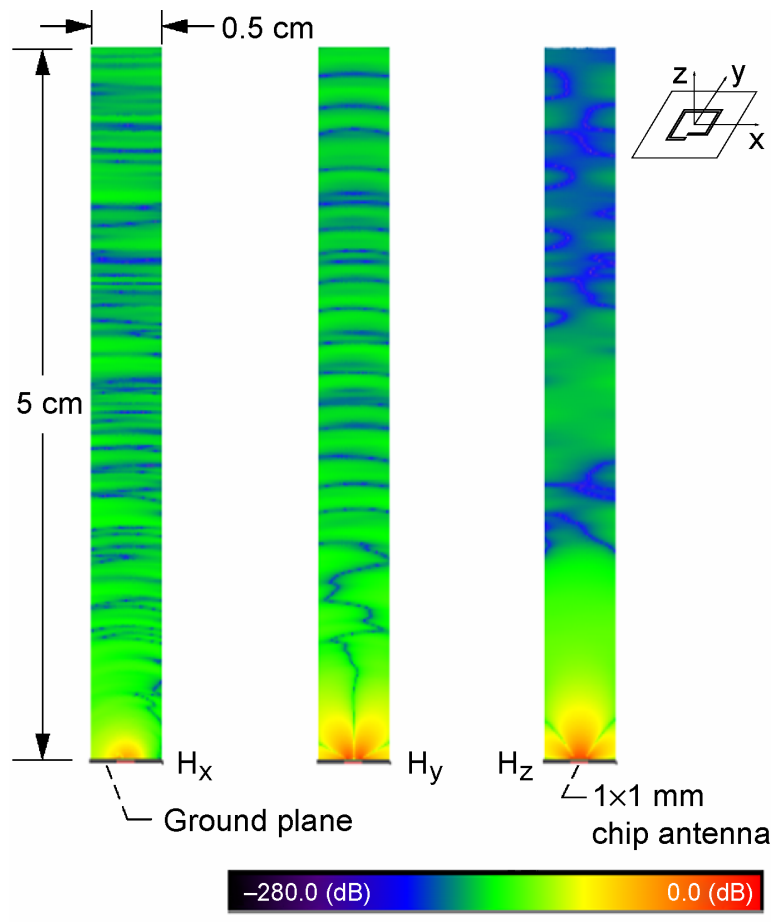

Figure 11.- Simulated intensity of the RF magnetic field components as a function of the distance from the center of a single-turn spiral antenna in the $y-z$ plane. Frequency $=403.5 \mathrm{MHz}, \mathrm{S}=\mathrm{W}=15 \mu \mathrm{m}$, $\mathrm{d}_{\text {out }}=1.0 \mathrm{~mm}$, substrate thickness and relative permittivity are $325 \mu \mathrm{m}$ and 11.7 .

Lastly, a practical sensor will be housed inside a biocompatible package. This package would be constructed typically from metal/ceramics and may have curved boundaries. Hence, additional simulations are necessary to accurately predict the near-zone magnetic field intensity around the package. 

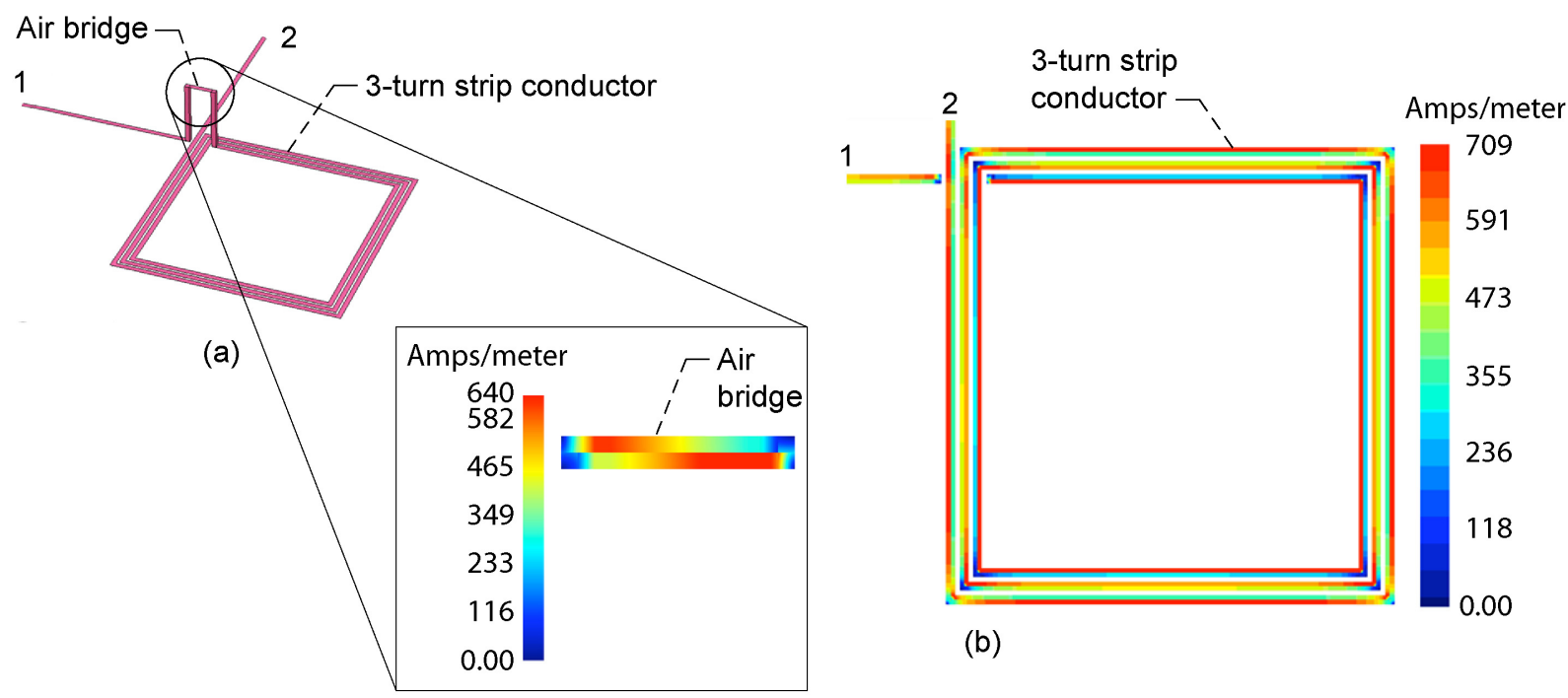

(b)

Figure 12.-Three-turn spiral inductor/antenna. (a) Geometry and simulated RF current density on air bridge.

(b) Simulated RF current density on the strip conductors

\section{Discussions and Conclusions}

A wearable wireless telemetry and contact-less powering scheme for an implantable bio-MEMS based sensor system is presented. A miniature printed square spiral chip antenna and a printed loop antenna are integrated with the sensor and the wearable garment, respectively for telemetry and inductive powering. The implantable sensor antenna is modeled as a square spiral chip inductor. The computed results presented include the inductance, the parasitic resistance, the capacitance and the near-zone RF magnetic field intensity pattern of the implantable antenna array. In addition, for the coupled chip and loop antennas, the mutual inductance and an equivalent circuit model are presented. Lastly, the computed intensity of the near-zone RF magnetic field components for a single-turn spiral and the current density on the strip conductors of a threeturn spiral using finite difference time domain and method of moments software tools, respectively, are presented.

As a concluding remark it may be mentioned that the miniature transmitters and receivers required for implantable sensor telemetry can be realized in sub-micron RF CMOS technology with DC power consumption on the order of few hundred microwatts (refs. 11 and 12).

\section{References}

1. C.W. Mundt, et al., "A Multiparameter Wearable Physiologic Monitoring System for Space and Terrestrial Applications," IEEE Trans. Info. Technology in Biomedicine, Vol. 9, No. 3, pp. 382-391, Sept. 2005.

2. R.N. Simons, D.G. Hall, and F.A. Miranda, "RF Telemetry System for an Implantable Bio-MEMS Sensor," IEEE MTT-S Inter. Microwave Symp. Dig., Vol. 3, pp. 14331436, Fort Worth, TX, June 6-11, 2004.
3. P. Bonato, "Wearable Sensors/Systems and Their Impact on Biomedical Engineering," IEEE Engineering in Medicine and Biology Magazine, Vol. 22, No. 3, pp. 18-20, May/June 2003.

4. S.S. Mohan, M.D.M. Hershenson, S.P. Boyd, and T.H. Lee, "Simple Accurate Expressions for Planar Spiral Inductances," IEEE Jour. Solid-State Circuits, Vol. 34, No. 10, pp. 1419-1424, Oct. 1999.

5. M.D.M. Hershenson, S.S. Mohan, S.P. Boyd, and T.H. Lee, "Optimization of Inductor Circuits via Geometric Programming," Proc. 36th Design Automation Conf., pp. 994-998, New Orleans, LA, June 21-25, 1999.

6. S. Ramo, J.R. Whinnery and T.V. Duzer, Fields and Waves in Communication Electronics, 3rd Edition, New York, NY: John Wiley and Sons, 1994, Section 4.7 and Example 4.7a.

7. R.N. Simons and F.A. Miranda, "Modeling of the NearField Coupling Between an External Loop and an Implantable Spiral Chip Antenna in Biosensor Systems," 2006 IEEE AP-S Inter. Symp. Antennas \& Propagation and USNC/URSI National Radio Science and AMEREM Meetings Dig., Vol. 2, pp. 1099-1102, Albuquerque, NM, July 9-14, 2006.

8. C.A. Balanis, Antenna Theory Analysis and Design, 2nd Edition, New York, NY: John Wiley and Sons, 1997, section 5.2.4, equation (5-24), Example 5.2, and equation (5-37a).

9. http://www.remcom.com.

10. http://www.sonnetsoftware.com

11. R. Rofougaran, T.H. Lin, F. Newberg, and W.J. Kaiser, "A Micro-Power CMOS RF Front-End for Embedded Wireless Devices," 1999 IEEE Radio Frequency Integrated Circuits Symp. Dig., pp. 17-20, Anaheim, CA, June 13-15, 1999.

12. N.M. Neihart and R.R. Harrison, "Micropower Circuits for Bidirectional Wireless Telemetry in Neural Recording Applications," IEEE Trans. Biomedical Engineering, Vol. 52, No. 11, pp. 1950-1959, Nov. 2005. 


\begin{tabular}{|c|c|c|c|}
\hline \multicolumn{3}{|c|}{ REPORT DOCUMENTATION PAGE } & $\begin{array}{l}\text { Form Approved } \\
\text { OMB No. 0704-0188 }\end{array}$ \\
\hline \multicolumn{4}{|c|}{ 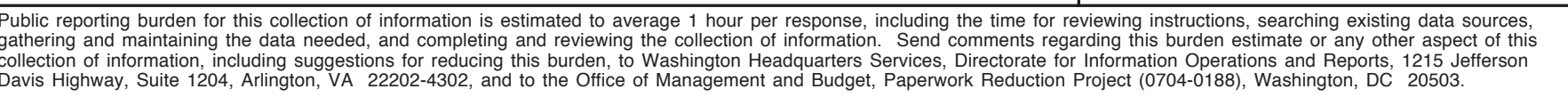 } \\
\hline 1. AGENCY USE ONLY (Leave blank) & $\begin{array}{r}\text { 2. REPORT DATE } \\
\text { October } 2006\end{array}$ & $\begin{array}{r}\text { 3. REPORT TYPE AI } \\
T\end{array}$ & $\begin{array}{l}\text { ID DATES COVERED } \\
\text { echnical Memorandum }\end{array}$ \\
\hline \multicolumn{3}{|c|}{$\begin{array}{l}\text { 4. TITLE AND SUBTITLE } \\
\text { Wearable Wireless Telemetry System for Implantable Bio-MEMS Sensors }\end{array}$} & 5. FUNDING NUMBERS \\
\hline $\begin{array}{l}\text { 6. AUTHOR(S) } \\
\text { Rainee N. Simons, Félix A. I }\end{array}$ & anda, Jeffrey D. Wilson & enita E. Simons & WBS $-22-252-92-80$ \\
\hline \multicolumn{3}{|c|}{$\begin{array}{l}\text { National Aeronautics and Space Administration } \\
\text { John H. Glenn Research Center at Lewis Field } \\
\text { Cleveland, Ohio } 44135-3191\end{array}$} & $\begin{array}{l}\text { 8. PERFORMING ORGANIZATION } \\
\text { REPORT NUMBER }\end{array}$ \\
\hline \multicolumn{3}{|c|}{$\begin{array}{l}\text { National Aeronautics and Space Administration } \\
\text { Washington, DC 20546-0001 }\end{array}$} & $\begin{array}{l}\text { 10. SPONSORING/MONITORING } \\
\text { AGENCY REPORT NUMBER } \\
\text { NASA TM-2006-214422 }\end{array}$ \\
\hline \multicolumn{4}{|c|}{$\begin{array}{l}\text { 11. SUPPLEMENTARY NOTES } \\
\text { Prepared for the 28th Annual International Conference (IEEE EMBC 2006) sponsored by the Institute of Electrical and } \\
\text { Electronics Engineers Engineering in Medicine and Biology Society, New York City, New York, August 30-September } 3 \text {, } \\
\text { 2006. Rainee N. Simons, Félix A. Miranda, and Jeffrey D. Wilson, NASA Glenn Research Center; and Renita E. Simons, } \\
\text { John Carroll University, 20700 North Park Boulevard, University Heights, Ohio 44118. Responsible person, Rainee N. } \\
\text { Simons, organization code RCE, 216-433-3462. }\end{array}$} \\
\hline \multicolumn{3}{|c|}{$\begin{array}{l}\text { 12a. DISTRIBUTION/AVAILABILITY STATEMENT } \\
\text { Unclassified - Unlimited } \\
\text { Subject Category: } 33 \\
\text { Available electronically at http://gltrs.grc.nasa.gov } \\
\text { This publication is available from the NASA Center for AeroSpace Information, 301-621-0390. }\end{array}$} & \\
\hline
\end{tabular}

In this paper, a telemetry and contact-less powering system consisting of an implantable bio-MEMS sensor with a miniature printed square spiral chip antenna and an external wearable garment with printed loop antenna is investigated. The wearable garment pick-up antenna and the implantable chip antenna are in close proximity to each other and hence couple inductively through their near-fields and behave as the primary and the secondary circuits of a transformer, respectively. The numerical and experimental results are graphically presented, and include the design parameter values as a function of the geometry, the relative RF magnetic near-field intensity as a function of the distance and angle, and the current density on the strip conductors, for the implantable chip antenna.

\begin{tabular}{|c|c|c|c|}
\hline \multicolumn{3}{|l|}{ 14. SUBJECT TERMS } & 15. NUMBER OF PAGES \\
\hline \multirow{2}{*}{\multicolumn{3}{|c|}{$\begin{array}{l}\text { Microelectromechanical systems; Wireless communications; Microwave sensors; } \\
\text { Bio-MEMS; Biotelemetry }\end{array}$}} & 11 \\
\hline & & & 16. PRICE CODE \\
\hline $\begin{array}{l}\text { 17. SECURITY CLASSIFICATION } \\
\text { OF REPORT }\end{array}$ & $\begin{array}{l}\text { 18. SECURITY CLASSIFICATION } \\
\text { OF THIS PAGE }\end{array}$ & $\begin{array}{l}\text { 19. SECURITY CLASSIFICATION } \\
\text { OF ABSTRACT }\end{array}$ & 20. LIMITATION OF ABSTRACT \\
\hline Unclassified & Unclassified & Unclassified & \\
\hline
\end{tabular}



